\title{
Gender Diversity in Research and Innovation Projects: The Proportion of Women in the Context of Higher Education
}

\author{
Natalia Restrepo ${ }^{1, *([)}$, Alfonso Unceta ${ }^{2}(\mathbb{1})$ and Xabier Barandiaran ${ }^{3}(\mathbb{C}$ \\ 1 Sinnergiak Social Innovation Centre, University of the Basque Country, 48940 San Sebastian, Spain \\ 2 Sociology 2 Department, University of the Basque Country, 48940 Leioa, Spain; alfonso.unceta@ehu.es \\ 3 Faculty of Social and Human Sciences, University of Deusto, 20012 San Sebastian, Spain; \\ xabier.barandiaran@deusto.es \\ * Correspondence: nrestrepo@sinnergiak.org
}

Citation: Restrepo, N.; Unceta, A.; Barandiaran, X. Gender Diversity in Research and Innovation Projects: The Proportion of Women in the Context of Higher Education.

Sustainability 2021, 13, 5111

https: / /doi.org/10.3390/su13095111

Academic Editors:

Carmen Botella-Mascarell,

Jordi Colomer Feliu, Anabel Forte

Deltell, Emilia López-Iñesta and

Silvia Rueda Pascual

Received: 11 March 2021

Accepted: 29 April 2021

Published: 2 May 2021

Publisher's Note: MDPI stays neutral with regard to jurisdictional claims in published maps and institutional affiliations.

Copyright: (c) 2021 by the authors. Licensee MDPI, Basel, Switzerland. This article is an open access article distributed under the terms and conditions of the Creative Commons Attribution (CC BY) license (https:/ / creativecommons.org/licenses/by/ $4.0 /)$.

\begin{abstract}
Europe has gradually consolidated its integration of the gender dimension in the field of research and innovation. Institutional structures have shown that the development of gender diversity policies have improved the conditions of equality between women and men. However, the representation of women in the workforce is still an everyday and universal concern. This article analyses the position of women in academic research. For this purpose, the evolution of the participation of women in research and innovation projects in the context of higher education is observed, taking the University of the Basque Country, Spain, as a case study. In order to evaluate the situation of women in research and innovation projects, the authors analyse a database with 75,864 records of projects collected between 2007 and 2018. The analysis confirms that a more balanced participation has been achieved between women and men in research and innovation teams and in project management structures. However, it also shows that gender diversity should continue to be a priority, in addition to its integration in science and technology financing programmes. Knowing this reality can be useful to promote the intensive development of public policies and to contribute towards the effort to improve the statistics of women's participation in science.
\end{abstract}

Keywords: women in science; European research area; R\&I projects; gender; Basque Country; universities

\section{Introduction}

Research is not the only field of activity where the gender equality agenda has been co-opted in the early 21st century [1]. In different political and academic contexts, there is an interest in strengthening the link between "women and science" in practice, in order to achieve a greater balance in their representation [2].

The main obstacle to study the presence of women in science is the lack of statistics that are systematically carried out and published. In 1999, the European Council of the 20th of May invited member states to contribute towards the shared goal of improving the statistics of women's participation in research [3]. Just during the last decade, there has been progress in the consolidation of studies with a gender perspective, with the aim of giving visibility to women's participation in science, in addition to measuring their participation in order to develop mechanisms and policies that promote equality between men and women [4]. These studies have shown that women do not enjoy the same opportunities as men when it comes to pursuing a professional career in science. The data in this regard are very clear and confirm that the higher up in the academic hierarchy, the lower the proportion of women [5].

This article aims to analyse the presence of women in science through their participation in research and innovation (hereafter R\&I) projects. For this purpose, the evolution of the participation of women in R\&I projects is observed, using the University of the Basque Country, Spain, as a case study. 
Thus, the article is structured into six sections: In Section 2, the theoretical foundation and related studies on women's participation in R\&I are reviewed. Policies and strategies developed in Europe also are examined. Section 3 presents the study area. Section 4 explains the methodological process, while Section 5 examines the results. Sections 6 and 7 conclude by highlighting some key features derived from the research.

\section{Gender Perspective in Research and Innovation}

Diversity can be defined as a characteristic of a group signifying demographic differences amongst group members in terms of race, ethnicity, gender, social class, religion, nationality, sexual identity or other dimensions of social identity that are marked by a history of intergroup prejudice, stigma or discrimination [6]. In the context of our study, we view gender diversity as a useful strategy that favours the application of the principle of equality between women and men [7]. More precisely, we focus on gender diversity on R\&I teams as a factor shown to increase the potential for innovation $[8,9]$.

In scientific careers, gender diversity is a persistent problem responsible for women's under-representation in senior positions with decision-making power [10]. Despite efforts to achieve gender diversity in research and innovation, difficulties remain in driving the development of an innovation system able to narrow the gender gap in science and innovation [11]. Therefore, studying women's participation in R\&I is crucial, both for innovation systems and research on gender. Although research on gender and R\&I has not been extensive, some studies in adjacent research areas have been influential (see Table 1).

Table 1. Recent perspectives on gender and R\&I studies. Source: Authors' elaboration.

\begin{tabular}{|c|c|c|}
\hline Authors & Topic & Study Area \\
\hline $\begin{array}{l}\text { Díaz-García, C.; González-Moreno, A.; } \\
\text { Saez-Martinez, F. (2014). [9]. }\end{array}$ & $\begin{array}{l}\text { Gender diversity within } R \& D \text { teams. Its } \\
\text { impact on radicalness of innovation. }\end{array}$ & Spain \\
\hline $\begin{array}{l}\text { Otero-Hermida, P.; García-Melón, M. } \\
\text { (2018). [12]. }\end{array}$ & $\begin{array}{l}\text { Gender equality indicators for Research } \\
\text { and Innovation } \\
\text { from a responsible perspective. }\end{array}$ & Spain \\
\hline $\begin{array}{l}\text { López-Iñesta, E.; Botella, C.; Rueda, S.; } \\
\text { Forte, A.; Marzal, P. (2020). [13]. }\end{array}$ & $\begin{array}{l}\text { Towards breaking the gender gap in } \\
\text { Science, Technology, Engineering and } \\
\text { Mathematics. }\end{array}$ & Spain \\
\hline $\begin{array}{c}\text { Cunningham, J.A.; Escribá-Esteve, A.; } \\
\text { Foncubierta-Rodríguez, M.J.; } \\
\text { Martín-Alcázar, F.; Perea-Vicente, J.L. } \\
\text { (2021). [14]. }\end{array}$ & $\begin{array}{l}\text { Gender study of principal investigator } \\
\text { lead public R\&D centres and funding. }\end{array}$ & Spain \\
\hline $\begin{array}{l}\text { Striebing, C.; Schmidt, E.K.; Palmén, R.; } \\
\text { Holzinger, F.; Nagy, B. (2020). [11]. }\end{array}$ & $\begin{array}{l}\text { Assessment of the contribution of gender } \\
\text { equality policies to Research and } \\
\text { Innovation. }\end{array}$ & Austria, Denmark, Hungary and Spain \\
\hline Nielsen, M.W. (2017). [15]. & $\begin{array}{l}\text { Scandinavian approaches to gender } \\
\text { equality in academia. A comparative } \\
\text { study. }\end{array}$ & Denmark, Norway and Sweden \\
\hline $\begin{array}{l}\text { Palmén, R.; Schmidt, E.K.; Striebing, C.; } \\
\text { Reidl, S.; Bührer, S.; Groó, D. (2019). [16]. }\end{array}$ & $\begin{array}{l}\text { Measuring gender in R\&I. Theories, } \\
\text { methods and experience. }\end{array}$ & Europe \\
\hline $\begin{array}{c}\text { Kalpazidou Schmidt, E.; Cacace, M. } \\
\text { (2017). [17]. }\end{array}$ & $\begin{array}{c}\text { Addressing gender inequality in science. } \\
\text { The multifaceted challenge of assessing } \\
\text { impact. }\end{array}$ & Europe, North America and Australia \\
\hline $\begin{array}{l}\text { Alsos, G.A.; Ljunggren, E.; Hytti, U. } \\
\text { (2013). [18]. }\end{array}$ & $\begin{array}{l}\text { Gender and innovation. State-of-the-art } \\
\text { and a research agenda. }\end{array}$ & General \\
\hline $\begin{array}{l}\text { Kalpazidou Schmidt, E.; Graversen, E.K. } \\
\text { (2020). [19]. }\end{array}$ & $\begin{array}{l}\text { Conceptual evaluation framework for } \\
\text { gender equality interventions in R\&I. }\end{array}$ & General \\
\hline
\end{tabular}


Despite recent interest in study issues concerning gender diversity in R\&I, the existing studies do not focus sufficiently on reflecting the proportion of women in the context of R\&I projects. In this vein, probably one of the most interesting and recent contributions has been made by Striebing et al. [11], who focus on analysing the share of women researchers in four national innovation systems, specifically, in Austria, Denmark, Hungary and Spain in the time period 2005-2015. The authors showed that the proportion of women among the highly educated has increased in all four countries, and this implies an increase in the proportion of women among research personnel. However, with the exception of Spain, there have been no significant changes in the participation of women in the labour market in the comparison countries [11]. In this context, Spain is particularly interesting, because, since the mid-2000s, there has been a strong legislative movement to incorporate women in the workforce and in top corporate positions [20]. In fact, studies by Díaz-García et al. [9] and López-Iñesta [13] have shown that having women on teams improves decision-making processes, enhances the sort of creativity that favours innovation and encourages R\&I teams to develop projects that involve important social changes.

On the other hand, Cunningham et al. [14] have found that there are no gender differences in relation to the acquisition of competitive funding in the context of the European Research Area (ERA), which is contrary to findings of other studies [21,22].

\section{Women in the European Research Area}

The European Research Area (ERA) is a unified space in which the research community, scientific knowledge and technology flow freely. The EU Commission launched this area in the year 2000. Its main objectives include the consolidation of a unified area-the optimisation of national and regional research programmes to achieve the consolidation of this field throughout Europe by coordinating these programmes. Recent reforms of the ERA focus on five priorities [23].

(1) Effectiveness of national research systems,

(2) Transnational cooperation on shared research agendas,

(3) Open labour market for researchers,

(4) Gender equality and the gender perspective in research,

(5) Circulation and transfer of scientific knowledge.

Also included within the framework of this area, defined in article 179 of the Treaty on the Functioning of the European Union, is the European R\&I Policy. The ERA instruments to achieve the established goals are materialised in the development of the Research and Development Framework programmes, such as the 7th Research and Development Framework Programme (2007-2013) replaced starting from 2014 by the Horizon 2020 Programme.

The strategies developed by the science and innovation systems of EU member states are carried out to a large extent under the guidelines of the European Research Area. Thus, all the initiatives and programmes designed in the different regional contexts take the priorities set out by the ERA as the foundation.

From the 1990s until 2008, most university graduates in Europe were women [24]. In the early 90 s, within the European university context, only $13.9 \%$ of teaching staff was represented by women [25]. This percentage of participation drops the higher up the academic professional category we go [26]. In 2008, only $15 \%$ of teaching staff in European universities were women; likewise, women were under-represented in scientific committees in almost all European countries, even in fields where the participation of women is normally representative: humanities, social sciences, biology [24].

Today, the variety of European policies show the effort made to remove the barriers that women find when rising in the academic sphere, and to advance in the development of their professional career. Thus, the current social context demands a solid commitment by the academic community in relation to equal gender opportunities [27]. 
In 1996, the European Commission introduced the concept of "gender mainstreaming", a policy to foster equality between women and men by the European Union. This policy was addressed with a three-pronged strategic approach:

(1) Equal treatment, guaranteeing that women and men receive the same treatment.

(2) Positive action, adopting positive actions to correct differences.

(3) Mainstreaming, integrating gender equality in systems, structures, institutions, programmes, policies and practices [28].

In scientific policy, mainstreaming was incorporated in the Communication from the European Commission "Women and Science. Mobilising women to enrich European research" [29]. This document proposed a strategy to promote research by, for and about women and invited the creation of a dynamic debate about women in science and to develop better inequality indicators [30]. This is how in the European Research Area, gender equality becomes a priority, as well as its integration in science and technology financing programmes.

In 2015, the ERA Roadmap (2015-2020) established that in relation to priority 4 "Gender Equality and Gender Mainstreaming in Research", the course of action should be to translate equality legislation into effective action in order to correct the gender imbalances in institutions and decision-making bodies in the field of research and to integrate the gender dimension in R\&I policies, programmes and projects [31].

In the framework programme for research and development in Europe, Horizon 2020, the gender equality strategy is based on three main objectives:

(1) To promote gender balance in research teams,

(2) To guarantee gender balance in decision-making ( $40 \%$ of female participation in panels and groups and $50 \%$ in advisory groups),

(3) Integration of the gender dimension in the content of research and innovation.

In the various calls for applications and subsidy programmes designed within the framework of this programme, there is a specific request to promote equal opportunities and a balanced participation of women and men in R\&I teams and in project management structures. In general, Horizon 2020 supports research organisations that promote active change through gender equality plans.

However, women are less represented than men in the grants assessed and awarded by the European Research Council (ERC), according to the data accumulated between 2007 and 2016 throughout the European Union [32]. From 2007 to 2016, around 26\% of all ERC applicants and $23 \%$ of all ERC grantees were women. At the same time, the proportion of female researchers among female R\&I staff is below the corresponding proportion of men in most member states.

Recent indicators, such as those mentioned in the She Figures (2018) report by the European Commission, show that the gender imbalance still persists in the field of researchonly one third of researchers in the EU are female. However, during the 2008-2015 period, the number of female researchers saw a rising rate of participation, higher than that of men (3.8\% for women and $3.4 \%$ for men). Within this context, it is important to highlight the presence of female researchers in the government sector, where $42.5 \%$ of researchers are women, and in the higher education sector, $42.1 \%$ [33]. On the other hand, in the business sector, women are still poorly represented, with $20.2 \%$ of the total number of researchers.

Although the participation rate of women in the European Research Area has slowly gained momentum, this transformation shows that in Europe, the integration of the gender dimension in research is becoming consolidated.

In this context, this article aims to analyse the presence of women in science through their participation in R\&I projects. For this purpose, the evolution of the participation of women in R\&I projects is observed, using the University of the Basque Country, Spain, as a case study. 


\section{Introduction to the Study Area}

\subsection{Women's Participation in the Spanish REI System}

When it joined the European Union, Spain acquired the commitment to adopt in its national legislation all European regulations, including those related to equality between women and men [34]. Gender equality in science is a recently created sphere of public intervention [4]. It was incorporated into science, universities and public research centres starting in 2004. Later, three of the most important interventions regarding this matter took place with Organic Law 3/2007, for the effective equality of women and men, the approval of Law 14/2011, on Science, Technology and Innovation and the design of the University Strategy in 2015 [4].

The participation of women in science and its evolution has been monitored by the Spanish Scientific Research Council (CSIC), an agency attached to the Spanish Ministry of Science, Innovation and Universities. The CSIC was a pioneer in the preparation of statistics on research staff broken down by sex in 2001 and with the creation of a Women and Science Commission (CMYC) in 2002.

On 10 January 2019, the Spanish government approved the creation of the Women, Science and Innovation Observatory (OMCI), for gender equality in the Spanish Science, Technology and Innovation System. As part of its functions, the OMCI evaluates the impact of gender equality policies, the situation of women and the activities of public agents in the Spanish science, technology and innovation system, as well making proposals to strengthen the situation of women in the system [35].

Preliminary analyses by the observatory reveal that the presence of women in Spanish universities and research centres is not equal. Despite their merits, women abandon their professional careers, and the higher the level of responsibility, the smaller the presence of women. This trend can be appreciated in the report Female Scientists in Figures (2021), carried out by the Spanish Ministry of Science, Innovation and Universities. The report analyses the relative presence of women at different levels of science in Spain, with a particular focus on research at universities and Public Research Bodies. In the 2018-2019 academic year, this report shows that the presence of women in universities and research centres, employee workforces and research teams in the Spanish science, technology and innovation system has increased in recent years, but is still far from being equal.

The statistics on R\&I activities by the Spanish National Statistics Institute [36] show that in 2019 , women only represented $40.6 \%$ of the total employment in research and development, and $39.9 \%$ of the total research staff. Spanish universities only include $24.1 \%$ of women among their full professors [35].

For the purpose of this article, it is of interest to bear in mind access to research financed with public funds. In this respect, the analysis of access to financing through applications submitted at the different calls for grants in Spain, specifically those requested between 2016 and 2019, shows that there are gender gaps. These gaps are highly visible in access to R\&I projects [35]. The proportion of grants awarded has been more successful for male Main Researchers, with $54.3 \%$, than for female Main Researchers, with $45.6 \%$ in the 2019 call.

The state scenario shows that although there has been considerable progress in the adoption of gender diversity policies in Spanish science, this is an area of intervention that still requires action to develop a culture of equality in science and to eliminate stereotypes in a field in which scientific references continue to be mostly male.

\subsection{Regional Context: Basque Autonomous Community}

In the Basque Country, the scientific community is structured around the Basque Network of Science, Technology and Innovation, formed by all the agents who are involved in the territory through actions focused on R\&I, including universities. In recent years, the Basque Scientific and Technological Policy has been developed within the framework of the Euskadi 2020 Science, Technology and Innovation Plan [37], establishing a clear goal to make the Basque Country an inclusive, innovative, reflexive and sustainable society in 
all fields, including equality between women and men. In this respect, the Euskadi 2020 Science, Technology and Innovation Plan recognises that addressing equality is a necessary value for the social and economic transformation of the Autonomous Community.

During the last decade, the participation of women throughout the Basque R\&I system has achieved a positive evolution, mainly highlighting the participation of female researchers within the Public Administration and universities (see Figure 1).

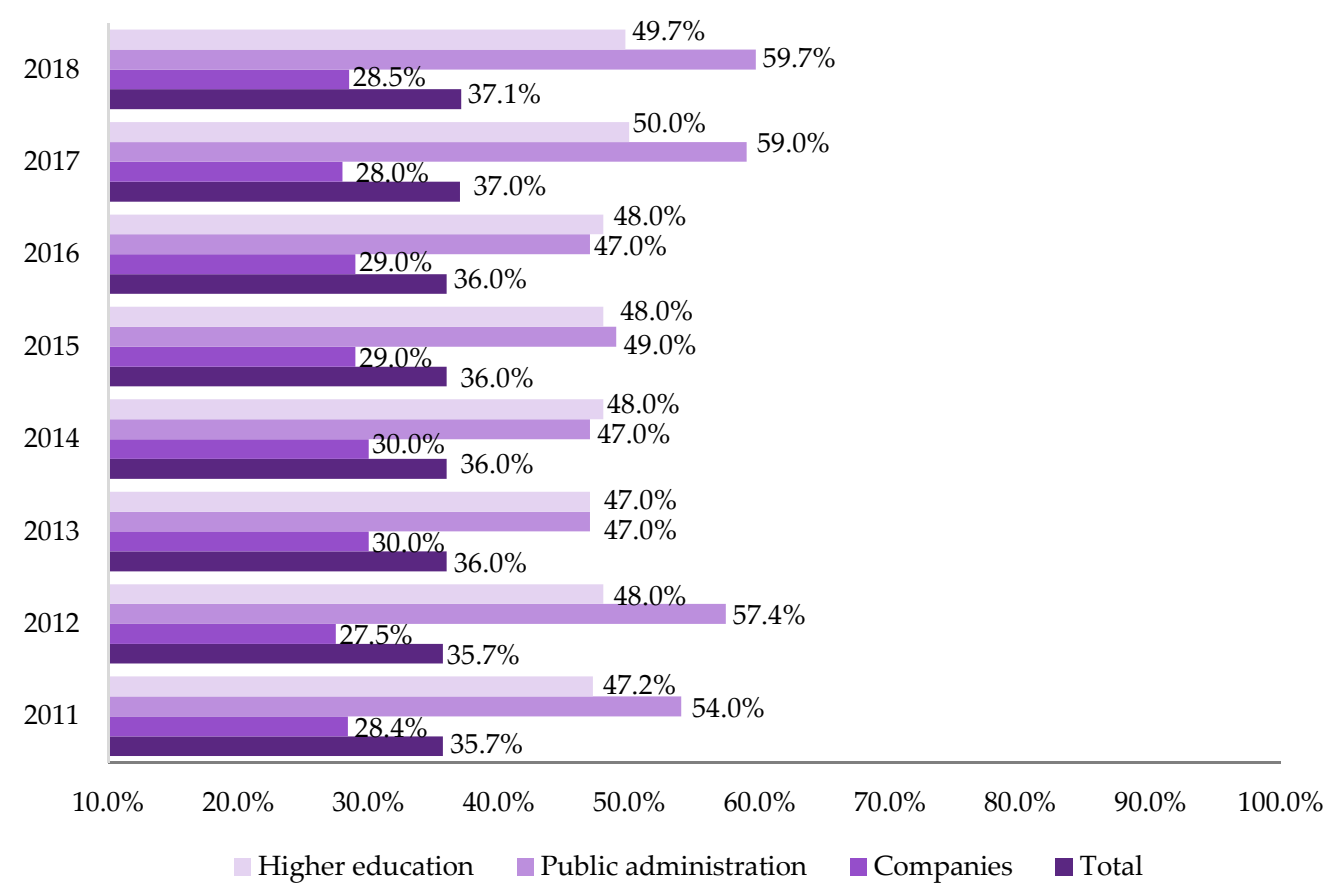

Figure 1. Evolution of the proportion of female researchers in the Basque Country and sector of activity, 2011-2018. Source: Authors' elaboration based on data of Eustat [38].

Although the representation of women in the Basque scientific sphere has improved over time, the proportion is still far from achieving an equal representation with respect to that of men. Significant evidence for this statement is the ratio of men and women who are members of staff of one of the most relevant institutions at a regional level, Ikerbasque. The Basque Foundation for Science-Ikerbasque, was created by the Basque Government to strengthen the Basque Science System through programmes to attract and consolidate researcher talent by hiring permanent researchers and/or promising young researchers who carry out their work at universities and research centres in the Basque Country (Figure 2).

Over the last decade, it has therefore been observed that in absolute values, there is a greater presence of male than female researchers in the Basque Foundation for ScienceIkerbasque. On the other hand, the Basque university system is composed of three universities. In these universities, in the three last academic periods, we can see a gender diversity in the University of Deusto (private). The University of the Basque Country (public) has maintained a positive trend of gender diversity, it highlights owing to the difficulty of affecting this indicator because of the high total volume of the institution's teaching and research staff (4.472). However, this gender diversity is reduced significantly in the University of Mondragon (Private), and this is an interesting point taking into account the prevalence of science, technology, engineering and mathematics (STEM) careers within the university (see Figure 3). 


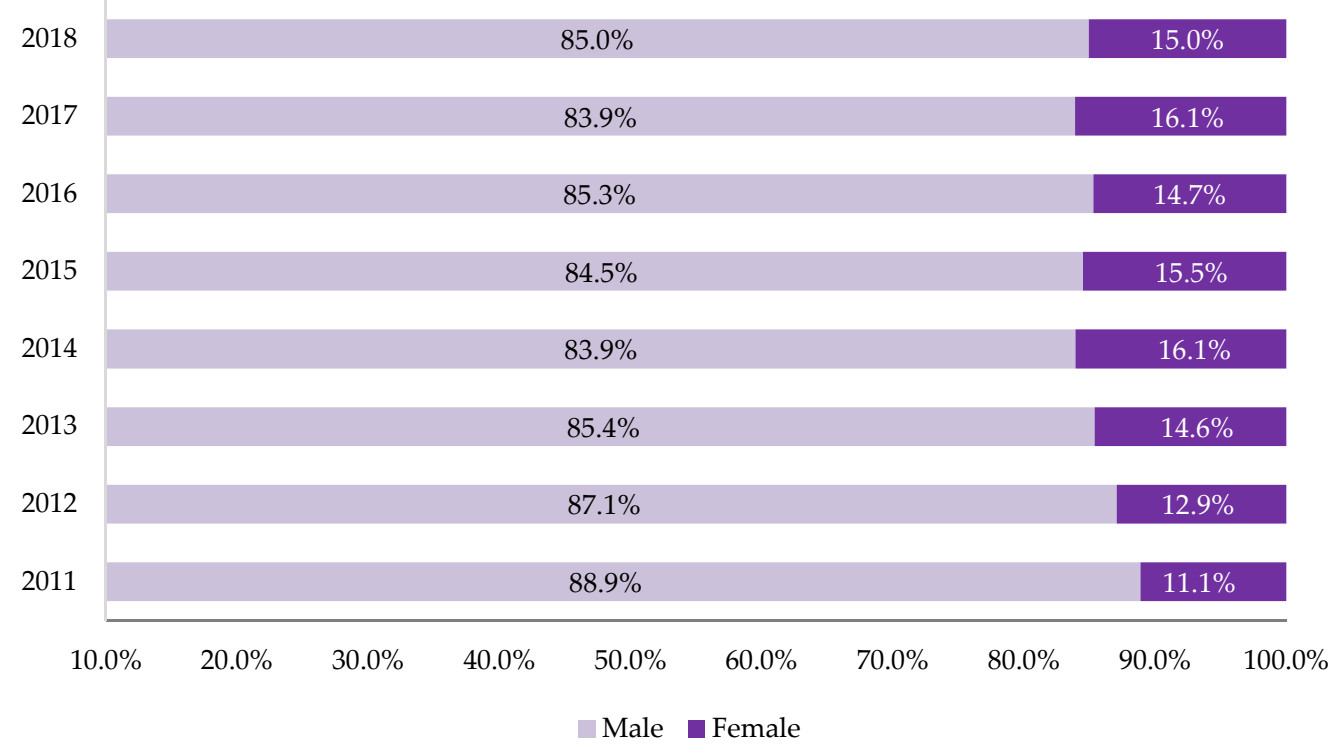

Figure 2. Evolution of permanent research staff at Ikerbasque, 2011-2018. Source: Authors' elaboration based on Ikerbasque data [39].

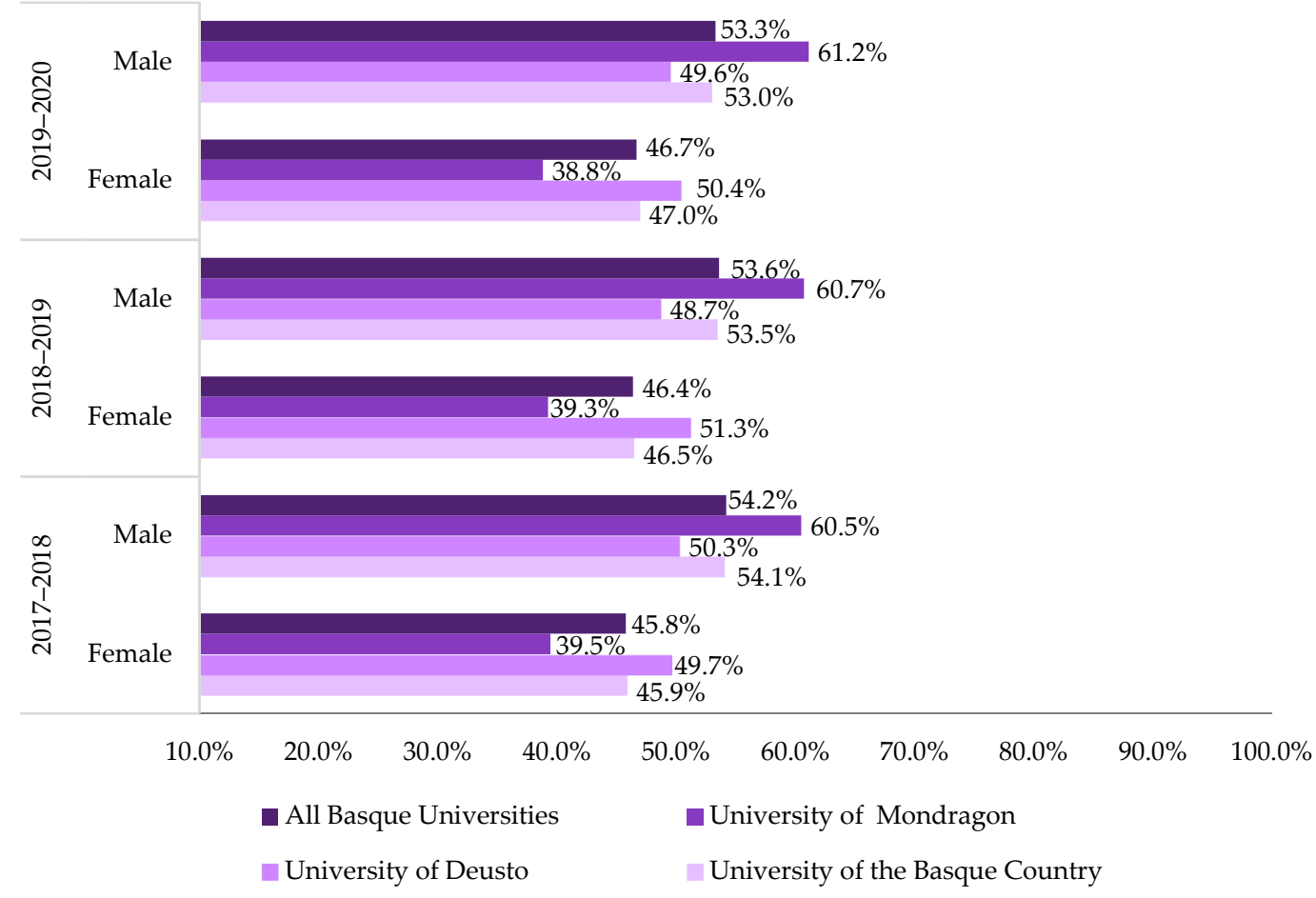

Figure 3. Gender diversity in teaching and research staff in universities in the Basque Country. Source: Authors' elaboration based on data of the EDUCAbase [40].

Nevertheless, these figures do not allow an appreciation of inequalities as regards the development of careers in research and access to positions of top responsibility throughout the autonomous community. In this respect, according to the Science Report 2020 [34] carried out by Ikerbasque, the gender gap increases as the research career advances, and this pattern is reproduced throughout the Basque Network of Science, Technology and Innovation, showing that this is cross-cutting problem throughout the Basque science system.

\subsection{University of the Basque Country}

The University of the Basque Country is located in northern Spain. It is the public University of the Basque Autonomous Community. The university has three campuses 
located in each one of the three provinces that form the Autonomous Community: Biscay, Gipuzkoa and Álava, and has a total of 19 faculties.

For the academic year 2018/2019, the students enrolled in the university totalled 51.681 , and 7.593 people were employed as teaching and research staff, and administration and services staff.

As for the development of gender diversity policies within the University of the Basque Country, the Governing Council of the university created the Directorate for Equality in the year 2006, to guarantee the effective equality of the rights and obligations of women and men at this university. The Directorate for Equality undertook the mission of preparing and developing the 1st Equality Plan, after carrying out a diagnosis of the situation of women and men. Thus, on 22 July 2010, the 1st Plan for the Equality of Women and Men of the University of the Basque Country (2010-2013) was approved. Under the framework of an Agreement of 3 April 2014, negotiating committees of the Teaching and Research Staff (TRS) and of the Administrative and Service Staff (ASS), the Inter-Sectoral Commission for Equality of the University of the Basque Country was created, a working body for the consultation, participation and, when necessary, negotiation of university staff representatives on the matter of equal treatment and opportunities for women and men.

\section{Methodology and Data}

This article analyses the presence of women in science through their participation in R\&I projects. Thus, the evolution of the participation of women in R\&I projects is observed, using the University of the Basque Country as a case study.

In order to develop the analysis, the primary source of information is a database with 75,864 records of R\&I projects collected between 2007 and 2018 within the University of the Basque Country. This database collects information from all projects submitted within the framework of project grant calls during the 2007-2018 period. The variables of interest included in the database are summarised in Table 2.

Table 2. Variables. Source: Authors' elaboration.

\begin{tabular}{|c|c|}
\hline \multirow{9}{*}{ Variables } & 1. Year \\
\hline & 2. Type of call \\
\hline & 3. Field of knowledge \\
\hline & 4. Gender \\
\hline & 5. Type of Participation \\
\hline & 6. Age Range \\
\hline & 7. Total Granted \\
\hline & 8. Category: PhD or Non-PhD \\
\hline & 9. Nature of the call \\
\hline
\end{tabular}

For the processing and statistical analysis of the data, the IBM SPSS Statistics software has been used. In this analysis and in order to adequately express the differences in the presence of women in research projects in the University of the Basque Country during the period studied of 2007-2018, the study of data is carried out by applying both a descriptive analysis through cross-tabulation, and a multivariate segmentation methodology or Chisquare Automatic Interaction Detection (CHAID).

The CHAID is a variant of the original AID (Automatic Interaction Detection) developed to segment a group and establish statistically disparate typologies when we find ourselves in a research situation that distinguishes between a dependent variable collected numerically (with a ratio or interval variable) and a set of independent variables collected in a nominal manner. In this case, as the variable is of a nominal or categorical nature, we apply a CHAID that operates with Chi-square instead of the variance analysis of the AID. These segmentation techniques have proven their usefulness in different fields and for 
different purposes, meaning that they are applied with increasing frequency in sociological, psychological or medical research [41].

In this segmentation analysis, as a dependent variable, the gender of the researcher from the database is used, and as independent variables, the following are analysed: type of call, field of knowledge and age range. The objective of the multivariate analysis of segmentation is to compare the resulting typology of projects in the year 2007 and in the year 2018 and to highlight the differences between them to evaluate the evolution of the proportion of women in R\&I projects in the University of the Basque Country.

In this framework, to determine the role of women in R\&I projects, three research hypotheses were set up:

Hypothesis 1 (H1). The proportion of women in REI projects in the University of the Basque Country has evolved positively.

Hypothesis 2 (H2). The new generations of women researchers have found a REI context that is more open and inclusive.

Hypothesis 3 (H3). There are gender differences in relation to the total amount granted for REI projects.

\section{Results}

\subsection{The Role of Women in REI Projects in the University of the Basque Country}

A univariate analysis has made it possible to obtain a developmental vision of the participation of women in R\&I projects in the University of the Basque Country between 2007 and 2018. In Figure 4, the figures show that 41.6\% (2.373) of the participating research staff in the year 2007 were women. This proportion presents a positive evolution over the course of the following 11 years, reaching a representation of $49.2 \%$ (3.560) in 2018, showing a more balanced male-female ratio that is advancing towards gender equality, in line with the fourth priority of the European Research Area.

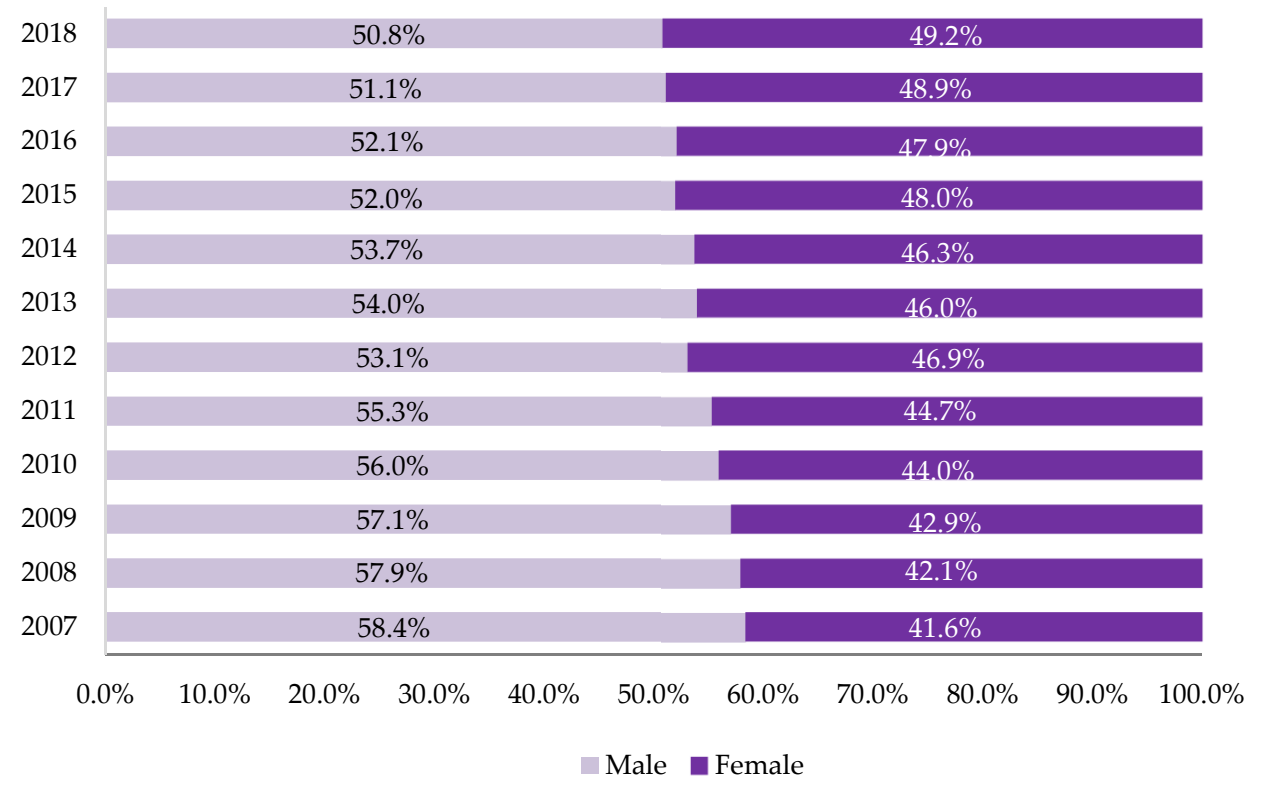

Figure 4. Male-female ratio in R\&I projects at the University of the Basque Country (UPV/EHU) 2007-2018. Source: Authors' elaboration.

On the other hand, in Figure 5, the data accumulated between 2007 and 2018 about the type of participation of women and men in R\&I projects in the University of the Basque Country show that the role played by women is to a larger extent as New Staff and a 
lower proportion as Main Researchers of the project team, achieving only 36.1\% (5.285) of representation between 2007 and 2018, which reveals the existence of barriers for women to achieve the role of top leadership in research and innovation projects and proving that there is still an under-representation of women in top-level positions.

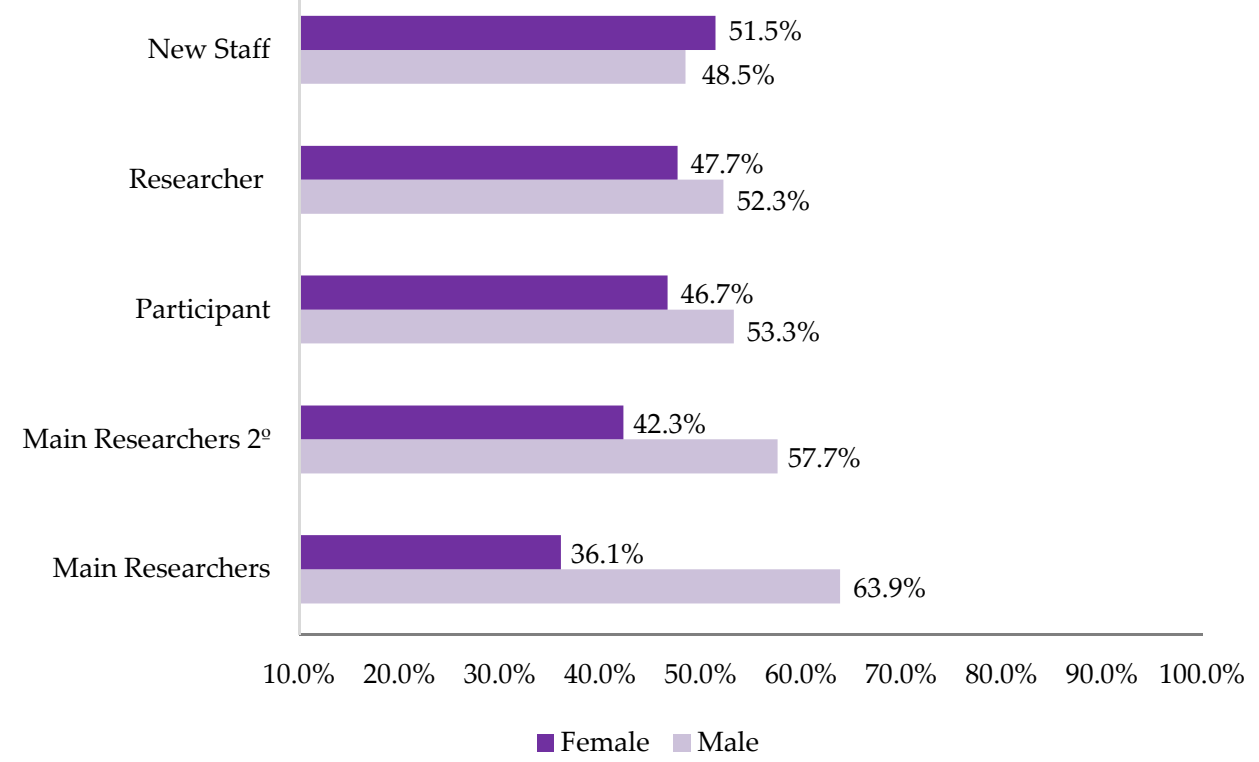

Figure 5. Role played in R\&I projects at the University of the Basque Country (UPV/EHU), accumulated ratio 2007-2018. Source: Authors' elaboration.

As for the level of education of the researchers participating in R\&I projects in the University of the Basque Country, Figure 6 highlights the fact that a large majority of women had the maximum academic level necessary to access the research career, that is, $78.6 \%$ (27.351) of the women had PhD's, with only 4.3 percentage points less than men, of which $82.9 \%$ (34.043) held PhD's.

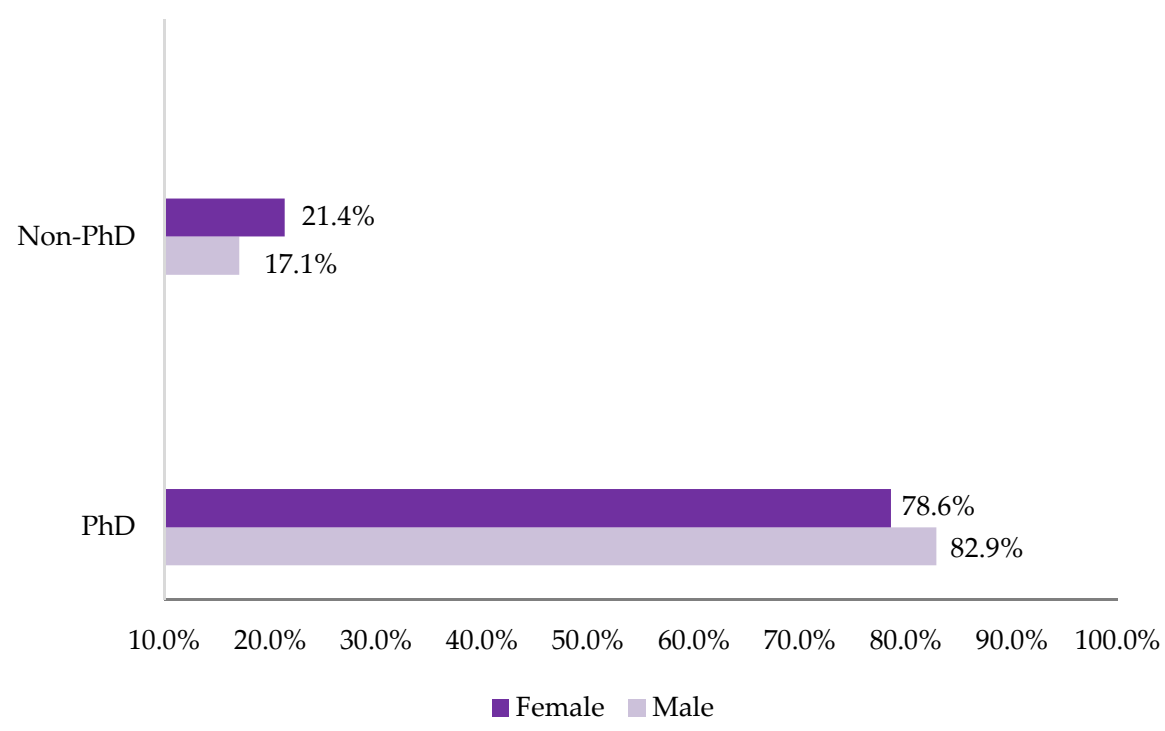

Figure 6. $\mathrm{PhD}$ and non-PhD research staff in R\&I projects at the University of the Basque Country (UPV /EHU), accumulated ratio 2007-2018. Source: Authors' elaboration.

In the following section, the multivariate analysis of segmentation-CHAID is presented with the aim of identifying the incidence variables in the segmentation of research staff 
participating in R\&I projects, with particular emphasis on the age range and the field of knowledge.

\subsection{Evolution of the Presence of Women in REI Projects: Age Range and Field of Knowledge}

The presence of women in R\&I projects in the University of the Basque Country has gone through significant changes during the 2007-2018 period analysed. As explained in Section 4, for data analysis, a multivariate analysis of Chi-square Automatic Interaction Detection (CHAID) segmentation was applied. CHAID segmentation consists of a statistical, multidirectional tree algorithm that explores data quickly and efficiently, creating typologies or profiles with respect to the pattern to be observed, in our case, the participation of women in R\&I projects in the University of the Basque Country.

The automatic detection of interactions used the researcher's gender as a dependent variable and the type of call, field of knowledge and age range as independent variables. To clarify the results, we should highlight that the CHAID application determined nodes in which the independent variables were significantly related to the researcher's gender (i.e., a dependent variable), which resulted in 11 types of projects for 2007 and 12 project typologies for 2018. In those typologies, the different degrees of women's participation and their unique characteristics indicate that the typologies and patterns of participation may have varied between the segmentation trees for 2007 and 2018.

From a general point of view, Figure 7 shows the typologies of the fields of knowledge, with the highest participation of women according to age range. Whereas 2007 was the starting point of the analysis, 2018 is the year until which we have access to data. The figures show the changes that have arisen in those 11 years, especially that, for all age ranges, the degree of women's participation in R\&I projects in engineering and architecture became diluted in 2018. That trend was most prominent in projects with research staff aged 66-75 years, only $9.8 \%$ of whom in 2018 were women.

In order to better express these differences, below, the multivariate analysis through the segmentation tree is presented. Thus, Figure 8 identifies 11 project typologies with a different level of presence of women.

The variables that predict a larger or smaller presence of women are, by order of importance, the age of the research staff (Significant, 0.000), field of knowledge (Significant, $0.000,0.001$ and 0.000 ) and type of call (Significant, 0.010). Organised from youngest to oldest age range, the typologies obtained are listed below (for more detailed information, see Appendix A).

- Typology 1: Projects with research staff aged 20 to 35 and from the fields of knowledge of Health Sciences and Arts and Humanities: 62.3\% corresponded to women. This is $4.1 \%$ of the total projects in 2007.

- Typology 2: Projects with research staff aged 20 to 35 and from the fields of knowledge of Sciences and Social and Legal Sciences, and from internal calls by the University of the Basque Country or at a provincial scale (Biscay, Gipuzkoa, Alava, Spain): 59.7\% corresponded to women. This is $4.1 \%$ of the total projects in 2007.

- Typology 3: Projects with research staff aged 20 to 35, from the fields Sciences and Social and Legal Sciences and from European, State or Autonomous region calls: $46.4 \%$ corresponded to women. This is $18.7 \%$ of the total projects in 2007.

- Typology 4: Projects with research staff aged 20 to 35 and from the field of Engineering and Architecture: $33.8 \%$ corresponded to women. This is $5.2 \%$ of the total projects in 2007.

- Typology 5: Projects with research staff aged 36 to 50 and from the field of knowledge of Health Sciences: $53.0 \%$ corresponded to women. This is $4.1 \%$ of the total projects in 2007.

- Typology 6: Projects with research staff aged 36 to 50 and from the fields of Sciences, Social and Legal Sciences and Arts and Humanities: $42.9 \%$ corresponded to women. This is $33.7 \%$ of the total projects in 2007 . 
- Typology 7: Projects with research staff aged 36 to 50 and from the field of Engineering and Architecture: $36.2 \%$ corresponded to women. This is $9.9 \%$ of the total projects in 2007.

- Typology 8: Projects with research staff aged 51 to 65 and from the field of Health Sciences: $52.3 \%$ corresponded to women. This is $1.9 \%$ of the total projects in 2007.

- Typology 9: Projects with research staff aged 51 to 65 and from the fields of Sciences and Social and Legal Sciences: $33.4 \%$ corresponded to women. This is $13.4 \%$ of the total projects in 2007.

- Typology 10: Projects with research staff aged 51 to 65 and from the fields of Engineering and Architecture and Arts and Humanities: 22.6\% corresponded to women. This is $6.2 \%$ of the total projects in 2007.

- Typology 11: Projects with research staff aged 66 to 75: $15.7 \%$ corresponded to women. This is $0.9 \%$ of the total projects in 2007 .

From this perspective, when we analyse the database of the projects in 2018, the most significant predictive variables are age (Significant, 0.000) and field of knowledge (Significant, 0.000, 0.024, 0.045, 0.000 and 0.048), as can be seen in Figure 9. This segment tree reflects the behaviour and changes in 2018, resulting in 12 project typologies, which are explained below and organised from youngest to oldest age range (for more detailed information, see Appendix B).

- Typology 1: Projects with research staff aged 20 to 35 and from the fields of knowledge of Health Sciences and Social and Legal Sciences: $69.7 \%$ correspond to women. This is $5.9 \%$ of the total projects in 2018.

- Typology 2: Projects with research staff aged 20 to 35 and from the fields of Sciences and Arts and Humanities: $57.5 \%$ correspond to women. This is $8.7 \%$ of the total projects in 2018.

- Typology 3: Projects with research staff aged 20 to 35 and from the field of knowledge of Engineering and Architecture: $49.9 \%$ correspond to women. This is $4.8 \%$ of the total projects in 2018. The presence of women in this typology has increased 15 points since 2007.

- Typology 4: Projects with research staff aged 36 to 50 and from the field of Health Sciences: $65.5 \%$ correspond to women. This is $7.9 \%$ of the total projects in 2018 .

- Typology 5: Projects with research staff aged 36 to 50 and from the field of Social and Legal Sciences: $59.8 \%$ correspond to women. This is $7.7 \%$ of the total projects in 2018 .

- Typology 6: Projects with research staff aged 36 to 50 and from the fields of knowledge of Sciences and Arts and Humanities: $50.4 \%$ correspond to women. This is $14.4 \%$ of the total projects in 2018.

- Typology 7: Projects with research staff aged 36 to 50 and from the field Engineering and Architecture: $43.1 \%$ correspond to women. This is $11.3 \%$ of the total projects in 2018.

- Typology 8: Projects with research staff aged 51 to 65 and from the field of Social and Legal Sciences: $47.5 \%$ correspond to women. This is $7.6 \%$ of the total projects in 2018 .

- Typology 9: Projects with research staff aged 51 to 65 and from the fields of Sciences and Health Sciences: $42.1 \%$ correspond to women. This is $16.0 \%$ of the total projects in 2018.

- Typology 10: Projects with research staff aged 51 to 65 and from the fields of Engineering and Architecture and Arts and Humanities: $37.7 \%$ correspond to women. This is $12.0 \%$ of the total projects in 2018.

- Typology 11: Projects with research staff aged 66 to 75 and from the fields of Social and Legal Sciences, Health Sciences, Sciences and Arts and Humanities: only 29.0\% correspond to women. This is $3.0 \%$ of the total projects in 2018.

- Typology 12: Projects with research staff aged 66 to 75 and from the field of Engineering and Architecture: only $9.8 \%$ correspond to women. This is $0.8 \%$ of the total projects in 2018. 


\section{7}

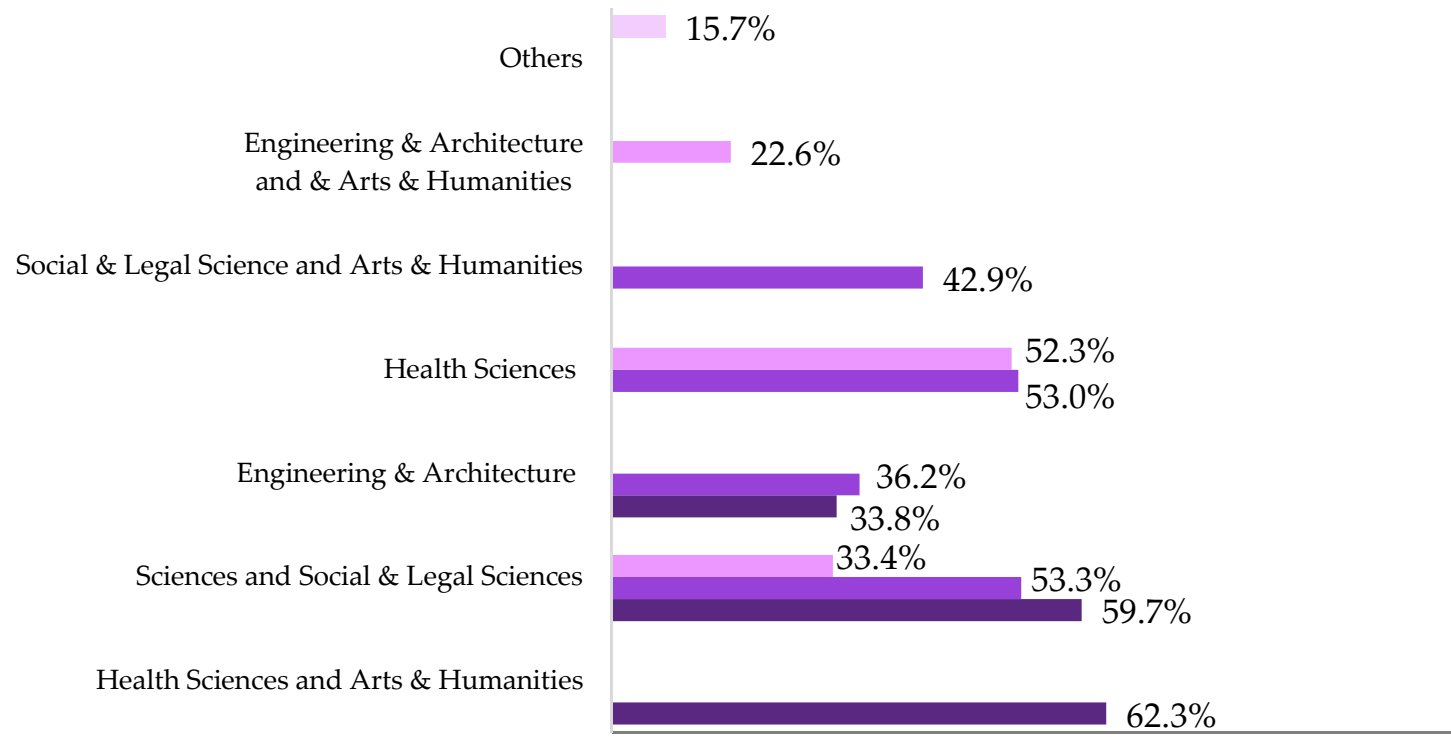

$\begin{array}{lllllllllll}10.0 \% & 20.0 \% & 30.0 \% & 40.0 \% & 50.0 \% & 60.0 \% & 70.0 \% & 80.0 \% & 90.0 \% & 100.0 \%\end{array}$ Aged 66 to $75 \square$ Aged 51 to $65 \square$ Aged 36 to $50 \square$ Aged 20 to 35

2018

Social \&

Legal Science, Health Sciences, Sciences...

Engineering \& Architecture

Sciences \& Health Sciences

Social \& Legal Science

Health Sciences

Engineering \&

Architecture and Arts \& Humanities

Sciences

and Arts \& Humanities

Health Sciences

and Social \& Legal Sciences
$29.0 \%$

\section{$9.8 \%$}

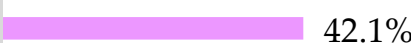

$47.5 \%$

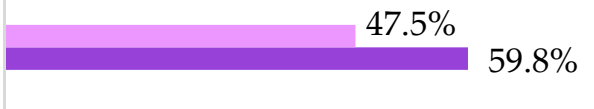

$65.5 \%$

\section{$37.7 \%$}

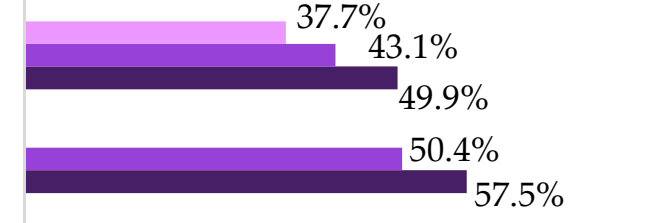

$69.7 \%$

$\begin{array}{lllllllllll}9.0 & 19.0 & 29.0 & 39.0 \% & 49.0 \% & 59.0 \% & 69.0 \% & 79.0 \% & 89.0 \% & 99.0 \%\end{array}$

Aged 66 to $75 \square$ Aged 51 to $65 \square$ Aged 36 to $50 \quad$ Aged 20 to 35

Figure 7. Overview of 2007 vs. 2018 of the typologies of the fields of knowledge with the participation of women according to age range. Source: Authors' elaboration. 


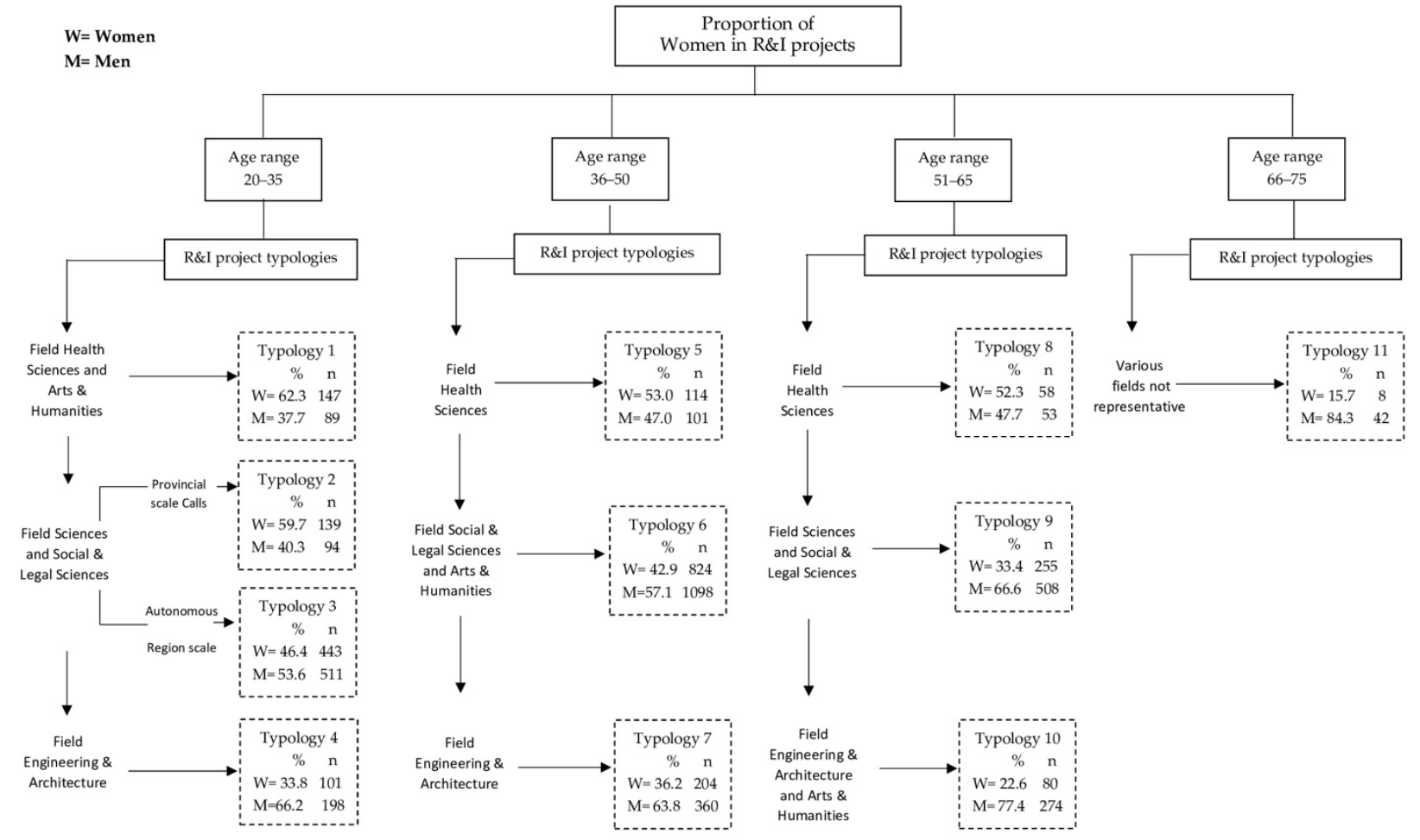

Figure 8. Segmentation tree: The Proportion of Women in R\&I projects UPV/EHU 2007.

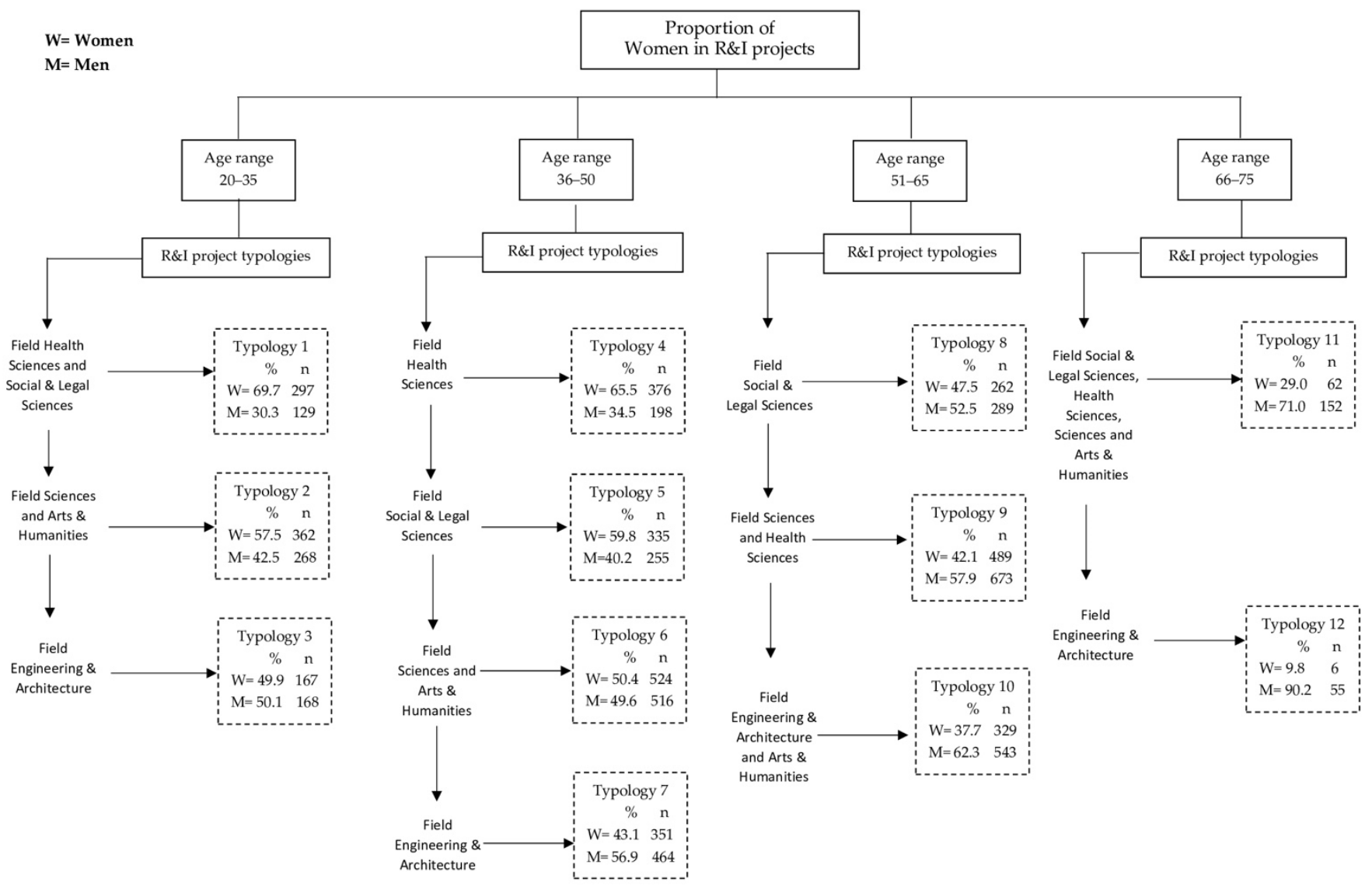

Figure 9. Segmentation tree: The Proportion of Women in R\&I projects UPV/EHU 2018. 
The last two typologies correspond to typology 11 of 2007, but while in typology 11 of 2018 the presence of women has increased significantly, typology 12 of 2018 shows the difficulties that pioneering women had in the field of Engineering and Architecture.

\subsection{Gender Diversity in Funding}

From 2007 to 2018, the University of the Basque Country registered a total of 15,732 projects funded by various international, national and regional organisations, including the University itself. Of them, $52.6 \%$ (8269) were granted to men and $47.4 \%$ (7463) to women.

Figure 10 shows the annual evolution in grant funding to R\&I projects between 2007 and 2018. Only in 2012 did funding granted to projects involving women exceed the funding received by men in the years analysed.

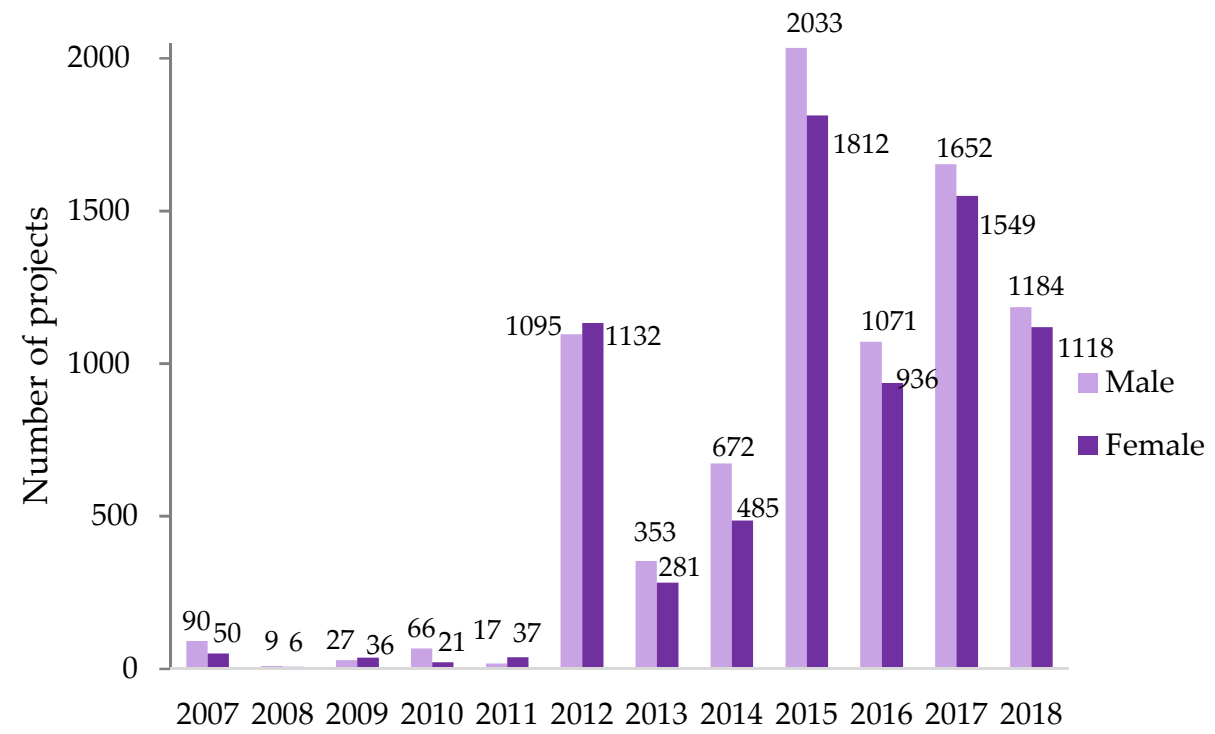

Figure 10. Annual evolution of the number of R\&I projects funded. Source: Authors' elaboration.

Regarding the amount of funding, Table 3 shows the accumulated funding requested and funding granted and their mean from 2007 to 2018 for projects led by men versus women.

Table 3. Accumulated funding requested and funding granted and the average per project from 2007 to 2018. Source: Authors' elaboration.

\begin{tabular}{ccccc}
\hline Type & Gender & Total Amount in EUR & $\%$ & $\begin{array}{c}\text { Average Amount per } \\
\text { Project in EUR }\end{array}$ \\
\hline \multirow{2}{*}{$\begin{array}{c}\text { Requested } \\
\text { funding }\end{array}$} & Men & $€ 7,585,164,690.92$ & $55.4 \%$ & $€ 184,774.18$ \\
\cline { 2 - 5 } & Women & $€ 6,118,014,860.18$ & $44.6 \%$ & $€ 175,764.62$ \\
\cline { 2 - 5 } & Total & $€ 13,703,179,551.10$ & $100.0 \%$ & $€ 180,269.40$ \\
\cline { 2 - 5 } Funding granted & Men & $€ 3,125,458,568.87$ & $55.2 \%$ & $€ 76,135.99$ \\
\cline { 2 - 5 } & Women & $€ 2,531,922,370.34$ & $44.8 \%$ & $€ 72,739.66$ \\
\hline
\end{tabular}

As shown, the absolute values of funding requested and granted differed by gender during the period analysed. However, those differences were slight and correlated with the amount requested in both cases. In men's case, the funding granted represented $41.2 \%$ of the amount requested; in women's case, it represented $41.4 \%$. 


\section{Discussion and Conclusions}

The gender diversity gap continues to be present in all economic, political and social spaces, and this reality is not unconnected to gaps in the field of science, technology and innovation. In the last decade, the gender gap in academic and scientific employment has attracted considerable attention [22]. To contribute to literature in that field, we examined women's degree of participation in R\&I projects in universities, represented by the University of the Basque Country, Spain.

The results obtained have made it possible to show that although there has been positive progress regarding the adoption of gender diversity policies in science, there are still obstacles for the full development of a scientific career among women.

In the case analysed, from 2007 to 2018, the University of the Basque Country evolved by increasing the involvement and representation of women in R\&I projects. Those results confirmed Hypothesis 1 (H1) and, beyond our study, validate the findings of Striebing et al. [11], who showed that the proportion of women among research personnel has increased in four European countries: Austria, Denmark, Hungary and Spain. When it comes to leading the management of projects or to participating as primary researchers, however, women's representation was diluted, which follows patterns shown in Spain's Basque Network of Science, Technology and Innovation, in its Science and Innovation systems and elsewhere in the European Union. In both contexts, the gender gap widened as the researcher's career lengthened, thereby indicating a challenge for the European Research Area (ERA) and its priority of gender diversity and mainstreaming in research.

The data show interesting findings about how the age range is a relevant factor for the existence of a greater participation of women in the field of research. In projects with research staff aged from 20 to 35, in most fields of knowledge, the presence of women is higher than $60.0 \%$ of representation. In the case of the age range between 51 and 65 , this presence is below $50.0 \%$, and from 66 to 75 , it is barely representative. This is an indication that pioneering female researchers have met greater barriers when making a space for themselves in professional research, while the new generations have found a context that is more open and inclusive. Therefore, this means that the Hypothesis 2 (H2) could also be confirmed. However, according to Lopez-Iñesta et al. [13], the number of women resigning from scientific and technological job positions has remained high. Along similar lines, our analysis revealed that the roles played by women in R\&I projects show the under-representation of women in top-level positions.

In addition, results showing changes that have arisen in the 11 years analysed highlight that, for all age ranges, the degree of women's participation in R\&I projects related to STEM disciplines became diluted. That finding reflects similar patterns demonstrated in the context of other universities in Spain, in which women's participation in STEM degrees has diminished since 2008. In that respect, Botella et al. [8] and Lopez-Iñesta [13] have highlighted the need for continued effort towards decreasing the gender diversity gap in all STEM-related degrees and jobs.

On the other hand, studies have also shown gender differences in the acquisition of competitive funding $[21,22]$. However, that pattern differs from reality in the University of the Basque Country, in which differences between the mean ratio in funding requested and funding granted according to gender, albeit confirming Hypothesis 3 (H3), were nevertheless minimal and thus reinforce Cunningham et al.'s [14] recent findings that no gender differences exist in the acquisition of competitive funding in the ERA.

At the same time, age is an important variable to consider in the representation of women in science. Findings evidence that in the postdoctoral stage, the proportion of women begins to decline, even though the number of women students and graduates has been greater than men for more than a decade in Spain. That pattern should be assessed and considered in the establishment and implementation of policies related to gender diversity in order to promote the employability and access of women to scientific jobs that span long-term careers. 
In this respect, our results have various implications for efforts geared towards overcoming the gender diversity gap in R\&I, specifically in the context of higher education. Higher education institutions should adopt gender equality plans, addressing the issues of increasing the visibility of female researchers and teachers [13].

Despite multiple policies developed in the ERA to generate better responses in the region, the educational and R\&I reforms by the innovation systems and the universities could promote the participation of women in their scientific careers even further. Added to that, the visibility of women researchers should be strengthened in universities offering a high prevalence of STEM-related degrees, given that women in STEM fields have experienced gender gaps and poor representation as women [8,42]. That factor is fundamental to achieving the UN's Sustainable Development Goals related to quality education (SDG4) and gender equality (SDG5). Achieving those goals expands opportunities for progress and promotes the development of communities that can ensure sustainable development [43]. Since women will be active agents in defining society's future [13], their participation in research, innovation and STEM disciplines is essential to achieving better solutions for global challenges [44].

\section{Limitations and Future Research}

It should be noted that the gender diversity gap in science and innovation is difficult to measure, as the data and indicators available at an international level are limited. This article draws attention to the importance of studying these phenomena of gender diversity in science, technology and innovation through an analysis of calls and projects destined to the development of R\&I within the entire system. However, future studies could shed light on the development of indicators oriented towards a more precise measurement of gender equality in science, to establish a firmer foundation of evidence that enables policymakers to assess and direct their efforts in this field and in R\&I financing programmes.

At the same time, researchers need to perform comparative studies at the micro level, ideally by studying patterns in women's participation in other universities. In that way, future research could capture a number of cases large enough to give the necessary validation to the findings presented here.

The research methods to be adopted in other studies should be qualitative or mixed and include in-depth interviews in order to explore women's perception of their role and presence in R\&I systems.

Author Contributions: Conceptualization, N.R., A.U. and X.B.; methodology, A.U. and N.R.; software, N.R.; data curation, A.U. and N.R.; writing-original draft preparation, N.R., A.U. and X.B. All authors have read and agreed to the published version of the manuscript.

Funding: This research received no external funding.

Institutional Review Board Statement: Not applicable.

Informed Consent Statement: Informed consent was obtained from all subjects involved in the study.

Data Availability Statement: The data and materials that support the findings of this study are available from the corresponding author.

Conflicts of Interest: The authors declare no conflict of interest. 


\section{Appendix A}

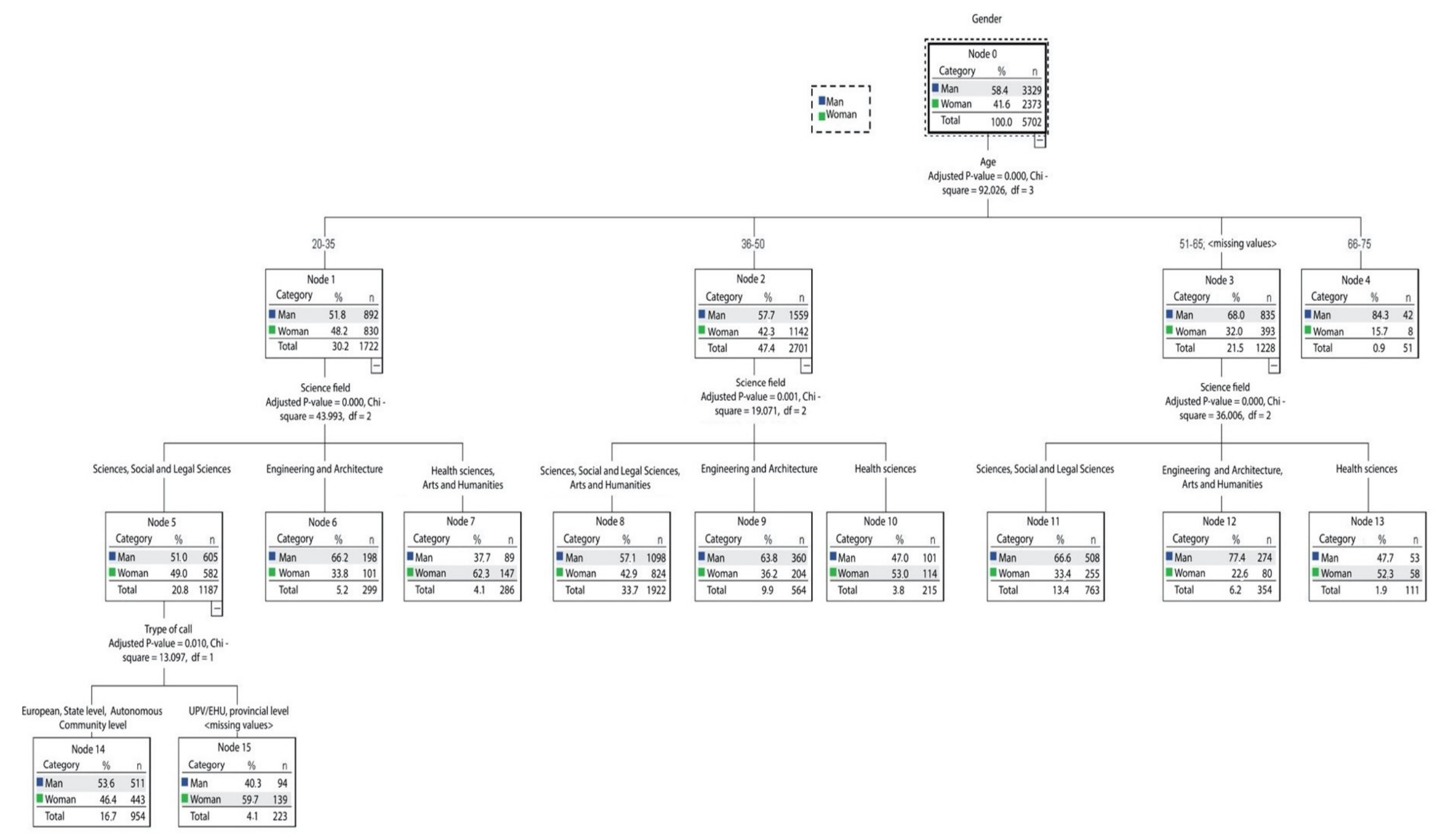

Figure A1. Segmentation Tree from SPSS Statistics: The Proportion of Women in R\&I projects UPV/EHU 2007. 


\section{Appendix B}

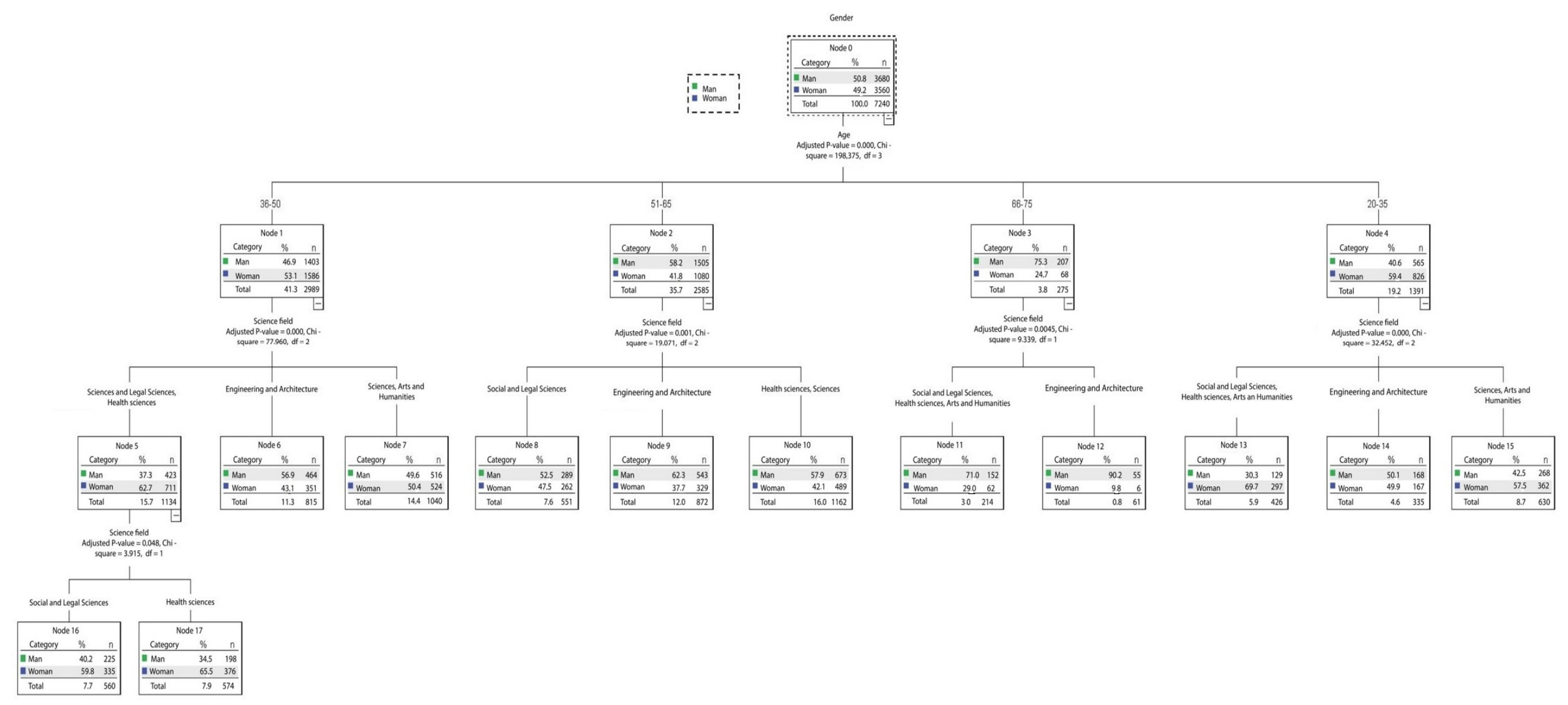

Figure A2. Segmentation Tree from SPSS Statistics: The Proportion of Women in R\&I projects UPV/EHU 2018. 


\section{References}

1. Stratigaki, M. Gender mainstreaming vs positive action: An ongoing conflict in EU gender equality policy. Eur. J. Women Stud. 2015, 12, 165-186. [CrossRef]

2. Linková, M.; Červinková, A. What matters to women in science? Gender, power and bureaucracy. Eur. J. Women Stud. 2011, 18, 215-230. [CrossRef]

3. González, T.; Pau, B. Techo de cristal y suelo pegajoso: La situación de la mujer en los sistemas alemán y español de ciencia y tecnología. CTS Rev. Iberoam. Cienc. Tecnol. Y Soc. 2011, 6, 35-59.

4. Delgado, L. La promoción de la igualdad de género en la ciencia española. Investig. Fem. 2015, 5, 232-258. [CrossRef]

5. Macho Stadler, M. Mujeres con Ciencia. Cátedra de Cultura Científica de la UPV/EHU. Available online: https: / / mujeresconciencia.com/ (accessed on 20 November 2020).

6. Ramarajan, L.; Thomas, D. A Positive Approach to Studying Diversity in Organizations. Available online: https:/ /papers.ssrn. com/sol3/papers.cfm?abstract_id=1674930 (accessed on 10 September 2010).

7. Barberá Heredia, E.B. Diversidad de género, igualdad de oportunidades y entornos laborales. CIRIEC Esp. 2004, 50, 37-53.

8. Botella, C.; Rueda, S.; López-Iñesta, E.; Marzal, P. Gender diversity in STEM disciplines: A multiple factor problem. Entropy 2019, 21, 30. [CrossRef]

9. Díaz-García, C.; González-Moreno, A.; Saez-Martinez, F. Gender diversity within R\&D teams: Its impact on radicalness of innovation. Innovation 2013, 15, 149-160.

10. Shen, H. Inequality quantified: Mind the gender gap. Nat. News. 2013, 495, 22.

11. Striebing, C.; Schmidt, E.K.; Palmén, R.; Holzinger, F.; Nagy, B. Women Underrepresentation in R\&I: A Sector Program Assessment of the Contribution of Gender Equality Policies in Research and Innovation. Eval. Progr. Plan. 2020, 79, 101749.

12. Otero-Hermida, P.; García-Melón, M. Gender Equality Indicators for Research and Innovation from a Responsible Perspective: The Case of Spain. Sustainability 2018, 10, 2980. [CrossRef]

13. López-Iñesta, E.; Botella, C.; Rueda, S.; Forte, A.; Marzal, P. Towards breaking the gender gap in Science, Technology, Engineering and Mathematics. IEEE Rev. Iberoam. Tecnol. Aprendiz. 2020, 15, 233-241.

14. Cunningham, J.A.; Escribá-Esteve, A.; Foncubierta-Rodríguez, M.J.; Martín-Alcázar, F.; Perea-Vicente, J.L. A gender study of principal investigator lead public R\&D centres and funding. Econ. Innov. New Technol. 2021, 1-16. [CrossRef]

15. Nielsen, M.W. Scandinavian approaches to gender equality in academia: A comparative study. Scand. J. Educ. Res. 2017, 61, 295-318. [CrossRef]

16. Palmén, R.; Schmidt, E.K.; Striebing, C.; Reidl, S.; Bührer, S.; Groó, D. Measuring gender in R\&I-theories, methods, and experience. Interdiscip. Sci. Rev. 2019, 44, 154-165.

17. Kalpazidou Schmidt, E.; Cacace, M. Addressing gender inequality in science: The multifaceted challenge of assessing impact. Res. Eval. 2017, 26, 102-114. [CrossRef]

18. Alsos, G.A.; Ljunggren, E.; Hytti, U. Gender and innovation: State of the art and a research agenda. Int. J. Gend. Entrep. 2013, 5, 236-256.

19. Kalpazidou Schmidt, E.; Graversen, E.K. Developing a conceptual evaluation framework for gender equality interventions in research and innovation. Eval. Progr. Plan. 2020, 79, 101750. [CrossRef]

20. Hernández-Lara, A.B.; Gonzales-Bustos, J.P.; Alarcón-Alarcón, A. Social Sustainability on Corporate Boards: The Effects of Female Family Members on R\&D. Sustainability 2021, 13, 1982. [CrossRef]

21. Mayer, S.J.; Rathmann, J.M. How does research productivity relate to gender? Analyzing gender differences for multiple publication dimensions. Scientometrics 2018, 117, 1663-1693. [CrossRef]

22. Lerchenmueller, M.J.; Sorenson, O. The gender gap in early career transitions in the life sciences. Res. Policy 2018, 47, 1007-1017. [CrossRef]

23. European Research Area-ERA. What Is ERA? Available online: https://ec.europa.eu/info/research-and-innovation/strategy/ era_en (accessed on 10 November 2020).

24. European Commission. Mapping the Maze: Getting More Women to the Top in Research. Available online: https://www. genderportal.eu/resources/mapping-maze-getting-more-women-top-research (accessed on 9 November 2020).

25. Acker, S. New perspectives on an old problem: The position of women academics in British higher education. High. Educ. 1991, 24, 57-75. [CrossRef]

26. Tomás, M.; Castro, D.; Durán, M. Aproximación a un modelo de análisis de la visibilidad en la universidad desde la perspectiva de género. Bordón. Rev. Pedag. 2011, 64, 141-158.

27. Lozano, I.; Iglesias, M.; Martínez, M. La cultura de la igualdad de oportunidades en el tejido universitario europeo. Rev. Interam. Investig. Educ. Y Pedag. 2013, 6, 31-59.

28. Rees, T. Mainstreaming Equality in the European Union; Routledge: London, UK, 1998.

29. European Commission. Women and Science: Mobilizing Women to Enrich European Research. COM (1999) 76. Available online: www.eur-lex.europa.eu/legal-content/EN/TXT/?uri=LEGISSUM\%3Ac10930 (accessed on 9 November 2020). 
30. European Commission. Science Policies in the European Union: Promoting Excellence through Mainstreaming Gender Equality. Available online: https://op.europa.eu/en/publication-detail/-/publication/4d456ad0-abb8-41a2-9d21-dbd5381f1f4c/ language-en (accessed on 9 November 2020).

31. Spanish Ministry of Science, Innovation and Universities. Científicas en Cifras 2015. Available online: https://www. ciencia.gob.es/stfls/MICINN/Ministerio/FICHEROS/Informe_Cientificas_en_Cifras_2015_con_Anexo.pdf (accessed on 10 November 2020).

32. SUPERA Project. Supporting the Promotion of Equality in Research and Academia. European Union's Horizon 2020 Research and Innovation Programme under Grant Agreement No. 787829. Available online: www.superaproject.eu (accessed on 10 November 2020).

33. European Commission. She Figures 2018. Report for the Department of Research and Innovation, Belgium, November 2020. Available online: https:/ / ec.europa.eu/info/publications/she-figures-2018_es (accessed on 26 January 2021).

34. Lombardo, E. El mainstreaming: La aplicación de la transversalidad en la Unión Europea. Aequalitas Rev. Juríd. Igual. Oportunidades Entre Mujeres Y Hombres 2003, 13, 6-11.

35. Spanish Ministry of Science, Innovation and Universities. Científicas en Cifras 2021. Available online: https://www.ciencia.gob. es/stfls/MICINN/Ministerio/FICHEROS/Cientificas_en_Cifras_2021.pdf (accessed on 10 April 2021).

36. Instituto Nacional de Estadística de España [INE]. Estadística Sobre las Actividades en Investigación Científica Y Desarrollo Tecnológico (I+D) 2019. Available online: https://www.ine.es / dyngs/INEbase/es / operacion.htm?c=Estadistica_C\&cid=125473 6176754\&menu=ultiDatos\&idp=1254735576669 (accessed on 10 April 2021).

37. Gobierno Vasco. Plan de Ciencia, Tecnología e Innovación Euskadi 2020. Available online: https:/ / www.euskadi.eus / gobiernovasco/pcti-2020/ (accessed on 2 November 2020).

38. Eustat. Personal Total Dedicado a I+D en la C.A. de Euskadi por Sector de Ejecución Según Ocupación Y Sexo. Available online: http://www.eustat.eus/elementos/ele0000200/Personal_total_dedicado_a_ID_en_la_CA_de_Euskadi_por_sector_de_ ejecucion_segun_ocupacion_y_sexo/tbl0000248_c.html (accessed on 2 November 2020).

39. Ikerbasque. Science in Euskadi 2020. Available online: https://www.ikerbasque.net/sites/default/files/files/INFORME\%20 DE\%20CIENCIA\%20EUSKADI\%202020\%20II.pdf (accessed on 2 November 2020).

40. EDUCAbase. University Statistics: Teaching and Research Staff (PDI). Available online: http://estadisticas.mecd.gob.es/ EducaDynPx/educabase/index.htm?type=pcaxis\&path=/Universitaria $/$ Personal $/$ EPU19\&file=pcaxis\&l=s0 (accessed on 20 March 2021).

41. Ang, R.; Goh, D. Predicting juvenile offending: A comparison of data mining methods. Int. J. Offender Ther. Comp. Crim. 2013, 57, 191-207. [CrossRef]

42. Melak, A.; Singh, S. Women's Participation and Factors Affecting Their Academic Performance in Engineering and Technology Education: A Study of Ethiopia. Sustainability 2021, 13, 2246. [CrossRef]

43. Di Fabio, A. The psychology of sustainability and sustainable development for well-being in organizations. Front. Psychol. 2017, 8, 1534. [CrossRef] [PubMed]

44. Benavent, X.; de Ves, E.; Forte, A.; Botella-Mascarell, C.; López-Iñesta, E.; Rueda, S.; Roger, S.; Perez, J.; Portalés, C.; Dura, E.; et al. Girls4STEM: Gender Diversity in STEM for a Sustainable Future. Sustainability 2020, 12, 6051. [CrossRef] 